\title{
THE PUBLIC PROCUREMENT BILL NEEDS BETTER ENFORCEMENT: A SUGGESTED PROVISION TO EMPOWER AND INCENTIVISE WHISTLE-BLOWERS
}

\author{
Jonathan Klaaren and Ryan Brunette
}

\section{(2020) 7 APPLJ 16}

\begin{abstract}
Among other reforms, South African public procurement law needs increased enforcement. The current draft Bill proposes some enforcement measures including a new Public Procurement Tribunal with adjudicative powers. We argue the draft Bill should be amended to empower and incentivise whistle-blowers through a qui tam mechanism. In this anti-fraud mechanism, government is afforded an opportunity to take up or intervene in the public interest in private claims lodged by whistleblowers, often with the assistance of law firms. We propose a draft statutory provision. To implement this mechanism, the necessary element of public sector oversight would need to be exercised either by the National Prosecuting Authority or by a legal unit within the draft Bill's proposed Public Procurement Regulator. The adoption of this public/private enforcement power in developing countries aligns with calibrated and effective regulatory power. While the efficacy of this mechanism should always be compared with that of alternatives, providing for enforcement in part through a tailored whistleblowing provision appears to be the best available alternative in the South African context. In South Africa, inserting a qui tam provision into public procurement law will take pressure off under-capacitated investigators and prosecutors and will recover to the fiscus at least some portion of the ill-gotten gains of procurement fraudsters.
\end{abstract}




\section{THE PUBLIC PROCUREMENT BILL NEEDS BETTER ENFORCEMENT: A SUGGESTED PROVISION TO EMPOWER AND INCENTIVISE WHISTLE-BLOWERS}

Jonathan Klaaren

BAHons, LLB, MA, PhD, JD

Professor, University of the Witwatersrand, School of Law and the Wits Institute for Social and Economic Research (WiSER)

and

Ryan Brunette*

Research Associate at the Public Affairs Research Institute, University of the Witwatersrand and University of Cape Town

\section{Introduction}

Among other reforms, South African public procurement law needs a tougher enforcement strategy. One way to achieve this is for the current draft Bill $^{1}$ to be amended to empower and incentivise whistle-blowers. After briefly noting the enforcement features currently proposed in the Bill, this comment suggests provisions to add to the draft legislation in order to empower and incentivise whistle-blowers. Comparative research in the area of public procurement suggests that such a mechanism is among the most powerful weapons against fraud and corruption in public purchasing of goods, services, and infrastructure. In earlier work, we have noted the importance of robust enforcement strategies, including this mechanism, in

\footnotetext{
* We are grateful for Geo Quinot's invitation to write and submit this piece, for the assistance and support of the Public Affairs Research Institute to our research on public procurement, and for the helpful comments of anonymous reviewers of the APPL. Any remaining errors and omissions are our own.

${ }^{1}$ Draft Public Procurement Bill, 2020.
} 
ensuring that the goals of the current public procurement reform process - begun in 2013 - are achieved. ${ }^{2}$

This reform process is important. Government's procurement budget is larger than its employee compensation budget. At around R926-billion in 2018, it accounts for about a fifth of South Africa's gross domestic product. At such a scale, public procurement is key to the South African state's operational efficiency and effectiveness. It is central to the country's politics and to allocative patterns in the broader economy. A prominent site of corruption, preferential procurement is simultaneously a fulcrum for South Africa's transformation into a society free of the racism and sexism of colonial and apartheid political economy.

The Public Procurement Bill, viewed against this background, might be seen as a grand compromise. It aims to construct - from the dozens of legislative improvisations of the last quarter of a century - a single, coherent legal framework for the entirety of South Africa's public procurement regime. The Bill defines and strengthens central regulatory and oversight authority in a proposed Public Procurement Regulator in the National Treasury. It includes specific provisions for conflicts of interest, debarment of suppliers and transparency. It prohibits outside interference in procurement functions. At the same time, the Bill promotes a more flexible and expanded approach to preferential procurement from black people, women, veterans, youth, and disabled people. It goes on to facilitate the formalisation of some existing practices, not yet explicitly authorised in South African law, such as geographical set asides in the allocation of contracts, to businesses located in specific provinces, municipalities, townships, and other underdeveloped areas. ${ }^{3}$ In summary, the Bill seeks to bolster public procurement ethics, even while it augments post-apartheid efforts to reshape patterns of ownership and control in South African capitalism. ${ }^{4}$

On the whole, the Bill thus gestures towards positive synergies between anticorruption and broad-based development. It aims to carve out wider channels for the economic empowerment of historically disadvantaged groups, at the same time that it

\footnotetext{
2 Brunette, Klaaren \& Nqaba 2019: 537-554; Brunette \& Klaaren 2020.

${ }^{3}$ Draft Public Procurement Bill, 2020, s 26.

${ }^{4}$ Sections 7, 10 and 16-25.
} 
works to better-regulate and harness emerging businesses to the public interest. ${ }^{5} \mathrm{We}$ believe, however, that the Bill does not follow through on this final commitment, insofar as it fails to underwrite public procurement law with a credible enforcement strategy.

\section{Enforcement strategies}

Certainly, there are provisions for enforcement. In addition to the ethics, integrity and transparency provisions noted, and beyond the formalisation of the Public Procurement Regulator within National Treasury, the current Bill proposes one new institutional feature that will contribute to the enforcement of the public procurement rules under the newly envisioned regime. This is an adjudication structure, the Public Procurement Tribunal. ${ }^{6}$ The Tribunal is distinct from the Public Procurement Regulator and is arguably responsive to the call made for such an institution in some of the influential research commissioned earlier in the reform process. ${ }^{7}$

As outlined in the Bill, the Tribunal is part of a process for resolving bidder or supplier disputes. The Regulator and the provincial treasuries are called upon to play an ombudsmen-type role within the procurement system. The Tribunal is a further, internal remedy, intended to trigger the duty to exhaust internal remedies in terms of section 7(2) of the Promotion of Administrative Justice Act, ${ }^{8}$ and will operate with review procedures largely taken from a judicial template. ${ }^{9}$ The draft Bill provides for judicial enforcement of final Tribunal orders once such orders are filed in the courts. ${ }^{10}$

Otherwise, the Bill tends to rest too heavily on public investigative and prosecutorial functions which are still in the process of rebuilding capacity after years of politicisation and deliberate de-capacitation. ${ }^{11}$ In our view, the Bill can support these functions by empowering whistle-blowers to bring civil claims for the recovery of damages suffered by the state as a result of procurement fraud and corruption. Moreover, these whistle-

\footnotetext{
${ }^{5}$ McCrudden 2009: 123-167.

${ }^{6}$ Draft Public Procurement Bill, 2020, s 99.

${ }^{7}$ Quinot 2014: 103-107, 116-118.

${ }^{8}$ Act 3 of 2000.

${ }^{9}$ Draft Public Procurement Bill, 2020, ss 99-113.

${ }^{10}$ Sections 113 and 118.

${ }^{11}$ The latter facts are currently being investigated by the Zondo Commission of Inquiry into Allegations of State Capture. An extensive archive of its proceedings is available here: https://sastatecapture.org.za/ (Accessed 2004-2020).
} 
blowers should be incentivised - from one perspective, made whole again for the sacrifices incurred in the course of their civic endeavours - by rewarding them with a specified percentage of damages won.

\section{Qui tam}

We propose that the Public Procurement Bill include a legal provision known as qui tam, an abbreviation of the Latin for "he who sues on behalf of the King as well as for himself." The essence of a qui tam provision is that it grants to some private persons the right to approach a court to enforce a public law. At the same time as allowing the private person through the courthouse door, it encourages such efforts with a reward for successful litigation.

Qui tam is ancient and it is versatile. A precursor was a prominent feature of Roman criminal law from the time of the death of Julius Caesar. Between the fourteenth and the nineteenth centuries, the always cash-scarce English crown resorted to it regularly. Qui tam provisions were key to the enforcement of laws dealing with such diverse subjects as religious observance, processes of economic production and trade, matters of public safety and environmental pollution, as well as electoral processes, bribery, and other forms of official corruption. ${ }^{12}$

The basic idea is simple and elegant. The incentivisation of whistle-blowing covers for gaps in political will and investigative capacity. Where inside information is difficult and costly to get to, qui tam draws this inside information out. This has the effects of both sowing distrust in corrupt combinations and encouraging whistle-blowers to break rank with the other fraudsters and come forward. In South Africa, Kenya and some other countries in Africa, a similar mechanism is present in the corporate leniency policy of the competition authorities, which has proved to be highly effective in disrupting price-fixing cartels. ${ }^{13}$

\footnotetext{
12 Braithwaite 2008: 66-67.

${ }^{13}$ Moodaliyar 2008: 157-177; Andiva \& Masereti: 321-339.
} 
In contemporary times, qui tam has been developed most rigorously in the United States and it is increasingly being adopted in other countries. ${ }^{14}$ The instrument has today largely been confined to civil claims for the recovery of damages suffered by the state in the course of public procurement and - another area of potentially important application in South Africa -- taxation. These damages must arise as a result of fraud or "reckless disregard for truth or falsity". Whistle-blowers who lodge claims with courts are encouraged to do so with the services of specialist law firms. Government is afforded an opportunity to take up the claim or intervene in proceedings in the public interest. Where damages are proved, the initial relators of the claim are rewarded with a specified percentage of recoveries. Courts have discretion to reduce or increase these rewards within stipulated bounds. They can compel claimants to pay the costs of defendants, as a way to disincentivise unethical, vexatious, and frivolous litigation. These sorts of adjustments are integral to the successful functioning of the mechanism. Information gathered in the course of qui tam proceedings can be used in subsequent prosecutorial actions.

In the United States, the remedy was put on a statutory basis during the Civil War under the federal False Claims Act and significantly amended in 1986. ${ }^{15}$ As Braithwaite explains,

"[t]he initiative for False Claims Act cases normally comes from whistleblowers within a wealthy corporation alleged to have perpetrated fraud against the government. The whistle-blower goes to a law firm that specializes in qui tam suits ... This is not private law to recover personal losses as in tort; it is a private right to enforce public law encouraged with reward for doing so ... Whistleblowers and other plaintiffs file lawsuits 'under seal', so that they are concealed from the public and the defendant until the government has time to decide if it wants to join the lawsuit." ${ }^{16}$

Depending on whether the state takes over the case or not, under the US scheme, the initiating private complainant may recover 15 to 30 percent of the damages eventually awarded by court.

\footnotetext{
${ }^{14}$ Department of Justice 2016.

${ }^{15}$ Meador \& Warren 1997/1998: 455-484.

${ }^{16}$ Braithwaite 2008: 67.
} 
South African courts would need to work out several questions, including the nature of this statutory claim, but have some experience on similar issues under the Competition Act $^{17}$ and the Prevention of Organised Crime Act. ${ }^{18}$ Parliamentary drafters and courts would need to take a view on whether single or double damages would be appropriate; we have proposed double damages in our model statutory provision below. ${ }^{19}$ While our competition regulatory framework has preferred turnover-based fines, here the appropriate unit of analysis would be percentage of loss recovered, in order to promote successful actions.

There is a vibrant debate concerning the efficacy and consequences of this method of private enforcement. A number of critics argue that the remedy merely encourages the practice of litigation unnecessarily. To some extent, empirical research has addressed and refuted those claims. ${ }^{20}$ As with the introduction of any mechanism there is potential for abuse, but the refinements considered above, developed in the United States, have proven reasonably effective at discouraging this.

Arguably, the adoption of this private enforcement power in developing countries aligns with calibrated and effective regulatory power. As Braithwaite has pointed out, "[t]he reason qui tam was invented in thirteenth-century England at around the same time that village-level generalist police was invented was to compensate for weakness in state regulatory capacity. Across the globe today it still might be true that where state capacity is weakest the case for reliance on qui tam is strongest". ${ }^{21}$

While the efficacy of this mechanism should always be compared with that of alternatives, providing for enforcement in part through a tailored whistleblowing provision appears to be the best available alternative in the South African context. ${ }^{22}$ In South Africa, particularly in the aftermath of state capture, it is interesting to note that the adoption of this specific remedy has been mooted as early as $2014 .{ }^{23}$ Were this

\footnotetext{
${ }^{17}$ Act 89 of 1998.

${ }^{18}$ Act 121 of 1998. Trustees for the time being of Children's Resource Centre Trust and Others v Pioneer Food (Pty) Ltd and Others 2013 (2) SA 213 (SCA).

${ }^{19}$ Fose v Minister of Safety and Security 1997 (3) SA 786 (CC).

${ }^{20}$ Engstrom 2012: 1244-1325.

${ }^{21}$ Braithwaite 2008: 82.

${ }^{22}$ Kovacic 1995/1996: 1799-1858.

${ }^{23}$ Marcus 2014.
} 
mechanism to be adopted, the necessary element of public sector oversight would need to be exercised either by the public prosecution service, the National Prosecuting Authority, or by a legal unit within the draft Bill's proposed regulatory unit, the Public Procurement Regulator. ${ }^{24}$

For the year ending September 2019, under its flagship False Claims Act, the United States Department of Justice reports qui tam settlements and judgements of over \$2billion, or $72 \%$ of all damages awarded for false claims. ${ }^{25}$ Since 1988 , the federal government has recovered \$44.7-billion through this mechanism. The United States has relatively low levels of procurement corruption and well-capacitated investigative and enforcement agencies. In South Africa, inserting a qui tam provision into public procurement law will take pressure off under-capacitated investigators and prosecutors. The returns to the fiscus are likely to be comparatively greater.

\section{Model provision}

We propose the following model provision to be included in the Public Procurement Bill:

\section{Administrative penalty and recovery of double damages for false procurement claims}

(1) Any person who knowingly submits a false procurement claim or a false claim related to procurement to a procuring entity or causes another to submit a false claim to a procuring entity or knowingly makes a false record or statement to get a false claim paid by a procuring entity or acts improperly in order to avoid paying a procuring entity violates this Act.

(2) A person violating this section is liable for a civil penalty of an amount to be prescribed but not exceeding R100 000 and is liable for damages in double the amount of the false claim or avoided payment; provided that

\footnotetext{
${ }^{24}$ Stephenson 2005: 93-173.

${ }^{25}$ Brunette \& Klaaren: 2020.
} 
if the person violating this section is the relator/informant, that person shall only be liable for the amount of the false claim or avoided payment.

(3) Any person, who shall be known as the relator, may file in confidence at a High Court a complaint and full information alleging a violation of this section.

(4) Such complaint shall remain in confidence for a prescribed period not to exceed 120 days and be subject to investigation by the Authority or by a delegated and legally qualified official of the Authority, who shall have full access to such complaint and full information.

(5) The Authority shall indicate, within a prescribed period not to exceed 120 days, whether the Authority will take on the case.

(6) If the Authority takes on the case, the relator shall be eligible to receive a prescribed percentage, not to exceed one quarter, of the damages recovered.

(7) If the Authority does not take on the case, the relator shall be eligible to proceed with the case and to receive a prescribed percentage, not to exceed one third, of the damages recovered.

(8) No relator shall be penalized or have adverse action taken against him or her for action taken in terms of this section and such penalty or adverse action is a violation of this Act.

(9) In consultation with the Minister of Justice and Constitutional Development, the Minister shall regulate the process authorized in this section.

\section{Conclusion}

We are in agreement with the general thrust of the draft Public Procurement Bill. To defeat corruption, South Africa cannot further constrain formal, legally-approved avenues of upward mobility. It must expand them to give people a path out of the illicit economy. The Public Procurement Bill provides for that with its enhanced provisions for preferential procurement. At the same time, new businesses that are fostered through preferential procurement will likely not be viable and developmental, unless the state incorporates them into processes that reliably compel them to deliver and improve efficiencies, productivity, and adherence to public goals. The Public 
Procurement Bill, in this latter respect, falls flat. It needs teeth, an enforcement strategy, and it will find it in the empowerment and incentivisation of civic action by whistle-blowers.

\section{Bibliography}

\section{Literature}

Andiva, B. \& Masereti, E. 2019. Cartel Enforcement: Adoption of a Leniency Programme in Kenya. In Klaaren, J., Roberts, S. \& Valodia, I. (Eds.). Competition and Regulation for Inclusive Growth in Southern Africa. Johannesburg: Jacana.

Braithwaite, J. 2008. Regulatory Capitalism: How It Works, Ideas for Making It Work Better. Cheltenham: Edward Elgar Publishing.

Braithwaite, J. 2013. Flipping Markets to Virtue with Qui Tam and Restorative Justice. Accounting, Organizations and Society 38(6-7): 458-468.

Brunette, R., Klaaren, J. \& Nqaba, P. 2019. Reform in the Contract State: Embedded Directions in Public Procurement Regulation in South Africa. Development Southern Africa 36(4): 537-554.

Brunette, R. \& Klaaren, J. 2020. Position Paper on Reform in Public Procurement in South Africa. Johannesburg: Public Affairs Research Institute.

Department of Justice (United States). 2016. The False Claims Act: A Primer. https://www.justice.gov/sites/default/files/civil/legacy/2011/04/22/C-

FRAUDS FCA Primer.pdf (Accessed 20-04-2020).

Engstrom, D.F. 2012. Harnessing the Private Attorney General: Evidence from Qui Tam Litigation. Columbia Law Review 112(6): 1244-1325.

Kovacic, W.E. 1995/1996. Whistleblower Bounty Lawsuits as Monitoring Devices in Government Contracting. Loyola of Los Angeles Law Review 29(4): 1799-1858.

Marcus, A. 2014. Broadening the Range of Incentives to Combat Corruption in South Africa (New York Law School). 
McCrudden, C. 2009. Social Policy Choices and the International and National Law of Government Procurement: South Africa as a Case Study. Acta Juridica 9: 123-167.

Meador. P. \& Warren, E.S. 1997/1998. The False Claims Act: A Civil War Relic Evolves into a Modern Weapon. Tennessee Law Review 65(2): 455-484.

Moodaliyar, K. 2008. Are Cartels Skating on Thin Ice: An Insight into the South African Corporate Leniency Policy. South African Law Journal 125(1): 157-177.

Quinot, G. 2014. An Institutional Legal Structure for Regulating Public Procurement in South Africa. http://africanprocurementlaw.org/ocporeport/ (Accessed 20-04-2020).

Stephenson, M.C. 2005. Public Regulation of Private Enforcement: The Case for Expanding the Role of Administrative Agencies. Virginia Law Review 91(1): 93-173.

\section{Legislation}

Draft Public Procurement Bill, 2020 http://africanprocurementlaw.org/wpcontent/uploads/2020/02/Public-Procurement-Bill-for-public-comment-19-Feb2020.pdf (Accessed 20-04-2020)

Competition Act 89 of 1998

Prevention of Organised Crime Act 121 of 1998

Promotion of Administrative Justice Act 3 of 2000

\section{Case law}

Fose v Minister of Safety and Security 1997 (3) SA 786 (CC).

Trustees for the time being of Children's Resource Centre Trust and Others v Pioneer Food (Pty) Ltd and Others 2013 (2) SA 213 (SCA) 